\title{
Export production and the distribution of fish larvae and their prey in a coastal jet frontal region*
}

\author{
Louis Fortier ${ }^{1}$, Maurice E. Levasseur ${ }^{2}$, René Drolet ${ }^{1}$, Jean-Claude Therriault $^{2}$ \\ ${ }^{1}$ Département de biologie, Université Laval, Ste-Foy, Québec, Canada G1K 7P4 \\ ${ }^{2}$ Division d'océanographie biologique, Ministère des Pêches et des Océans, Institut Maurice Lamontagne, CP 1000, \\ Mont-Joli, Québec, Canada G5H 3 Z4
}

\begin{abstract}
Fine-scale spatial sampling series and vertical cross-sections were used to obtain quasisynoptic images of the distribution of fish larvae and their prey in the permanent frontal region formed by the Gaspê coastal jet current and the adjacent Anticosti gyre (NW Gulf of St. Lawrence, Canada). The accumulation of large diatoms triggered the reproduction of copepods in the Gaspé current where eggs and nauplii (the main prey of first-feeding fish larvae) were 10 to 20 times more abundant than in the gyre. Estuarine circulation resulted in the coincidence of the small and abundant larvae of capelin Mallotus villosus and sand lance Ammodytes sp. with this intense production of their food in the jet current. The large and less abundant larvae of redfish Sebastes sp. and Arctic shanny Stichaeus punctatus exploited the scarcer food resources of the Anticosti gyre. We conclude that opportunistic species producing large numbers of small offspring with limited foraging skills depend on massive export production at hydrographic singularities (i.e. salient hydrographic features) for reproduction. Species producing fewer but larger and more competent larvae can colonize less productive areas of the ocean. Plankton dynamics in the dispersal area of the early larval stages appear to be a primary constraint defining the life strategy of a fish species.
\end{abstract}

\section{INTRODUCTION}

Recent syntheses suggest that there are 2 distinct plankton food webs in the oceans: the microbial web and the short or traditional food chain (Goldman 1988, Cushing 1989, Legendre \& Le Fèvre 1989). In the microbial web, production by small phytoplankton cells $(<5 \mu \mathrm{m})$ is exploited by several trophic levels (e.g. bacteria, protozoa, appendicularians). Most of the primary production is respired within the euphotic zone and little energy is exported to large grazers (Caron et al. 1985). In the short food chain, large phytoplankton cells $(>5 \mu \mathrm{m})$ are exported from the euphotic zone by sedimentation or grazed by copepods.

\footnotetext{
- Contribution to the research programs of GIROQ (Groupe interuniversitaire de recherches océanographiques du Québec) and Institut Maurice Lamontagne (Department of Fisheries and Oceans Canada)
}

At the scale of the global ocean, export production leading to the short food chain is a relatively infrequent event that takes place primarily at hydrographic singularities (Legendre \& Le Fèvre 1989). Massive reproduction of herbivores, in particular copepods, will occur when export production persists or when large cells are prevented from sinking to the bottom by the hydrography. Hydrographic singularities supporting the short food chain and the reproduction of copepods include, for example, the vernal stratification of the water column in the North Atlantic (e.g. Parsons \& Lalli 1988), tidal fronts (e.g. Kiørboe et al. 1988, Chenoweth et al. 1989, Fortier \& Gagné 1990), and upwellings or fronts associated with coastal jet currents (e.g. Boyd \& Smith 1983, Hutchings et al. 1986, Smith et al. 1986) (see also Kiørboe et al. 1990 and Kiørboe 1991 for reviews). Since copepod eggs and nauplii are the main prey of a majority of fish larvae at first feeding (Last 1980, Turner 1984), the spawning of dominant fish species is expected to be associated with recurrent 
hydrographic singularities where the short food chain develops and copepods reproduce en masse. Cushing (1989) and Kiørboe (1991) suggested that the great fisheries of the world are rooted in such recurrent singularities.

In the Gaspé coastal jet current (see Fig. 1), the thermohaline stratification of nutrient-rich waters from the St. Lawrence estuary favors the proliferation of large diatoms (Sevigny et al. 1979, Levasseur et al. in press). Several authors have suggested that the spawning and dispersion strategies of forage fishes such as capelin Mallotus villosus and sand lance Ammodytes sp. exploit the high productivity of Gaspé current surface waters (Parent \& Brunel 1976, Jacquaz et al. 1977, de Lafontaine et al. 1984, Fortier et al. 1987). In this study, we describe the distribution of phytoplankton, copepod eggs and nauplii, and fish larvae across the frontal region between the Gaspé current and the Anticosti gyre. In particular, we address the hypothesis that the spawning strategies of marine fish seek to disperse first-feeding larvae in hydrographic areas where the production of large diatoms (export production) is high and the short food chain develops.

\section{MATERIALS AND METHODS}

Study area. The Gaspé current (NW Gulf of St. Lawrence) is a quasi-permanent buoyancy-driven coastal jet resulting from the seaward advection of the diluted waters of the St. Lawrence estuary along the Gaspé peninsula (El-Sabh 1976, Tang 1980a) (Fig. 1a). In cross-section, the current forms a $30 \mathrm{~m}$ thick, wedge-shaped layer separated by a strong halocline from an intermediate cold layer $\left(<0{ }^{\circ} \mathrm{C}\right)$ that forms during winter cooling (Forrester 1964). Horizontally, the current extends from the south shore to about $15 \mathrm{~km}$ offshore. The northeastward flow of the current (up to $110 \mathrm{~cm} \mathrm{~s}^{-1}$ in spring; Benoit et al. 1985) is reinforced by the cyclonic Anticosti gyre in the central basin (Tang 1980a) (Fig. 1b). Cross-frontal mixing and upwelling along the strong density front separating the Gaspé current from the Anticosti gyre have been described by Tang (1983) and Levasseur et al. (in press).

Oscillations of the inshore-offshore position of the current due to instabilities of the geostrophic flow have been observed dur- ing the summer (Tang 1980b). These events last for about $10 \mathrm{~d}$ and may occur once or twice during the summer. Apart from these disruptions of the current pattern, the structure and position of the coastal jet are stable (Tang 1980b) and cross-sections taken on a given day will be representative of the conditions prevailing over several days.

Sampling. Quasi-synoptic images of the cross-frontal distribution of phytoplankton, fish larvae and their

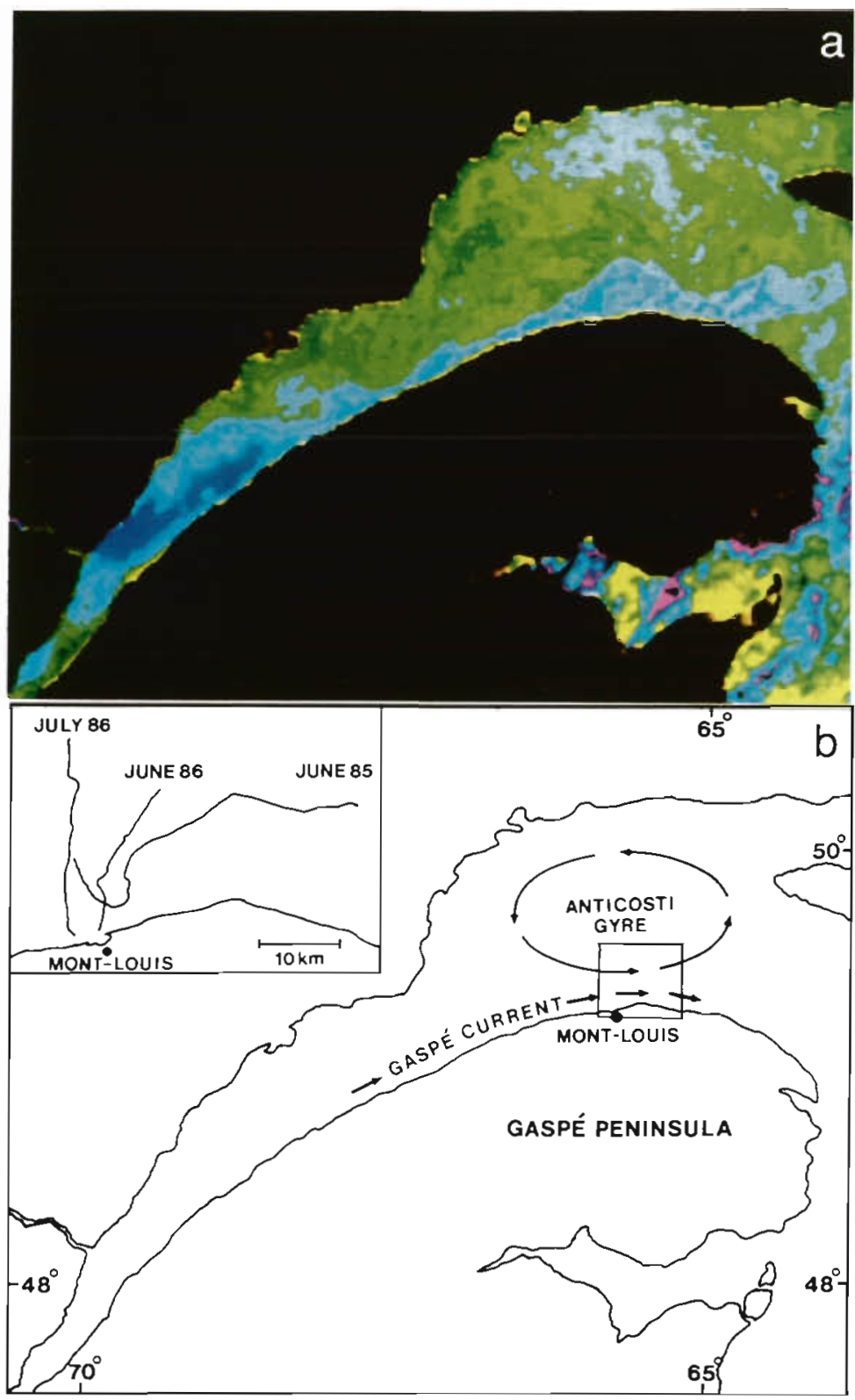

Fig. 1. Estuary and northwestern Gulf of St. Lawrence. (a) Satellite thermograph (NOAA, 18:27 h, 18 August 1987) illustrating the Gaspé coastal jet current (in light blue) flowing along the Gaspé peninsula. (b) Schematic representation of the main features of the surface circulation in the region. Inset: position of sampling transects in 1985 and 1986 
microzooplankton prey were obtained in the spring and early summer of 1985 and 1986. Zooplankton collections were made at close spatial intervals along offshore-inshore transects as the ship steamed at low speed across the frontal region. Chlorophyll a (chl a), fluorescence, temperature and salinity were monitored simultaneously.

Fish larvae and zooplankton were sampled with a $330 \mu \mathrm{m}$ (in 1985) or $250 \mu \mathrm{m}$ (in 1986) mesh net, mounted on a $1 \mathrm{~m}^{2}$ metal frame. The net was fitted with external and internal flowmeters and a 31 rigid codend with $80 \mu \mathrm{m}$ mesh apertures. A built-in depressor enabled us to cast the sampler in a rapid double-oblique tow to a depth of $25 \mathrm{~m}$. The tow lasted $80 \mathrm{~s}$ on average (SD $=$ $7.1 \mathrm{~s}, \mathrm{n}=521$ tows) while the ship steamed at an average speed of $1.67 \mathrm{~m} \mathrm{~s}^{-1}$ ( $3.1 \mathrm{knots}$ ) ( $\mathrm{SD}=0.11 \mathrm{~m} \mathrm{~s}^{-1}, \mathrm{n}=4262$ measurements). Upon retrieval, the net was thoroughly rinsed and the codend replaced in less than $150 \mathrm{~s}$. Casts were repeated at intervals of $240 \mathrm{~s}$ ( $4 \mathrm{~min}$ ). The crossfrontal transects therefore consisted in a series of tows, each covering an average distance of $134 \mathrm{~m}\left(1.67 \mathrm{~m} \mathrm{~s}^{-1}\right.$ $\times 80$ s) and separated from the next one by an unsampled interval of $267 \mathrm{~m}\left(1.67 \mathrm{~m} \mathrm{~s}^{-1} \times 160 \mathrm{~s}\right)$, for an overall distance of $401 \mathrm{~m}(\mathrm{SD}=14.6 \mathrm{~m})$ between the starting points of consecutive tows.

During the sampling transects, water temperature, salinity, as well as ship speed and direction relative to the water were recorded at $30 \mathrm{~s}$ intervals with Aanderaa RCM-5 instruments suspended from the side at depths of 1,5 , and $10 \mathrm{~m}$. Water was pumped from $3 \mathrm{~m}$ for the continuous monitoring of chl a fluorescence with a Turner design flow-through fluorometer. To calibrate the fluorescence signal, the concentration of chl a was determined (Yentsch \& Menzel 1963) in water samples collected at 15 min intervals at the output of the fluorometer. The fluorescence signal $(F)$ was transformed into chl a units $\left(\mathrm{mg} \mathrm{m}^{-3}\right)$ using the calibration relationship Chl $a=(F-0.3562) / 0.1212$ ( $\left.\mathrm{n}=98, \mathrm{r}^{2}=0.855, \mathrm{p}<0.001\right)$. Subsamples were preserved in Lugol for later enumeration and identification of phytoplankton cells using the Utermohl technique.

On 3 and 4 June 1985, a first cross-frontal transect of 360 zooplankton samples was obtained over a period of $24 \mathrm{~h}$. Starting some $30 \mathrm{~km}$ offshore in the Anticosti gyre, the ship first travelled westward parallel to the front for $8 \mathrm{~h}$, then south across the frontal region for the next $8 \mathrm{~h}$ and then westward again for the next $8 \mathrm{~h}$, against the eastward Gaspé current (Fig. 1b). To assess the cross-frontal vertical distribution and composition of the phytoplankton, 3 stations located in the Gaspé current, the front, and the Anticosti gyre respectively were occupied $48 \mathrm{~h}$ after the transect. Water samples were collected from different depths by raising the intake hose of a submersible pump from $40 \mathrm{~m}$ to the surface in steps of $2 \mathrm{~m}$, pausing for $2 \mathrm{~min}$ at each interval to ensure that the water originated from the correct depth. Chl a concentration at each depth and the taxonomic composition of the phytoplankton at selected depths were determined using the methods described above.

In 1986, a second ( 3 June) and a third (12 July) sampling transect comprising 76 and 85 zooplankton samples respectively were obtained along north-south transects off Mont-Louis with the sampler described above (Fig. 1b). Again, water temperature, salinity, and ship speed and direction (Aanderaa RCM-5 at 1,5, and $10 \mathrm{~m}$ ) as well as chl a fluorescence at $3 \mathrm{~m}$ were recorded. In addition to these measurements, a highresolution cross-section of temperature and salinity was obtained during the first transect ( 3 June) by towing a vertically oscillating CTD probe between 1 and $90 \mathrm{~m}$ (Endeco V-FIN system model 1074).

The sampling approach used along the cross-frontal transects allowed for a good spatial resolution of zooplankton density in the 0 to $25 \mathrm{~m}$ depth layer, but provided no information on the vertical distribution of the organisms and their abundance at depths $>25 \mathrm{~m}$. On 10 July 1986, a different sampler was used to assess the vertical distribution of fish larvae and their prey in the 0 to $90 \mathrm{~m}$ depth range across the frontal region. A $1 \mathrm{~m}^{2}$ multiple net sampler (Eastern Marine Services E-ZNet system) was deployed at 12 stations along the north-south transect off Mont-Louis. The sampler was fitted with $250 \mu \mathrm{m}$ mesh nets, $80 \mu \mathrm{m}$ mesh rigid codends, General Oceanic flowmeters, and an Applied Microsystems CTD probe. At each station, 9 depth layers of approximately $10 \mathrm{~m}$ each were sampled from $90 \mathrm{~m}$ to the surface, except at the station nearest to shore where nine $5 \mathrm{~m}$ depth intervals were sampled from $45 \mathrm{~m}$ to the surface because of reduced depth.

Sample analysis. Plankton samples were preserved in $4 \%$ neutral formalin. All fish larvae were sorted and identified. In each sample, all or up to a maximum of 50 larvae of the dominant species were measured to the nearest $0.1 \mathrm{~mm}$. The prey of the dominant species were determined by analyzing the gut contents of a subset of the larvae collected in 1985.

Estimates of the relative abundance of larval fish prey were based on the enumeration of the microzooplankton organisms retained by the $80 \mu \mathrm{m}$ mesh of the rigid codend. Numbers were tentatively transformed into densities (no. $\mathrm{m}^{-3}$ ) by assuming that the volume of water filtered on the $80 \mu \mathrm{m}$ mesh was equal to the product of the codend aperture $\left(0.008 \mathrm{~m}^{2}\right)$ and the length of the tow. These estimates of relative abundance allow for comparisons between samples. Absolute values of density should be considered with caution, however, because of the uncertainty in the estimation of the actual volume of water filtered. The enumeration of the micro- 
times more abundant in the Gaspé current than in the front or the Anticosti gyre. The diatom assemblage was dominated by Thalassiosira spp. in the current and the front and by Chaetoceros spp. and Leptocylindricus spp. in the gyre (Table 1). Vertically, the high phytoplankton biomass found in the Gaspé current was distributed in the 0 to $10 \mathrm{~m}$ layer above the pycnocline (Fig. 3a). Phytoplankton biomass was concentrated at the pycnocline ( 8 to $10 \mathrm{~m}$ ) in the front (Fig. 3b) and between 20 and $27 \mathrm{~m}$ in the Anticosti gyre (Fig. 3c).

\section{SALINITY $(\%)$}

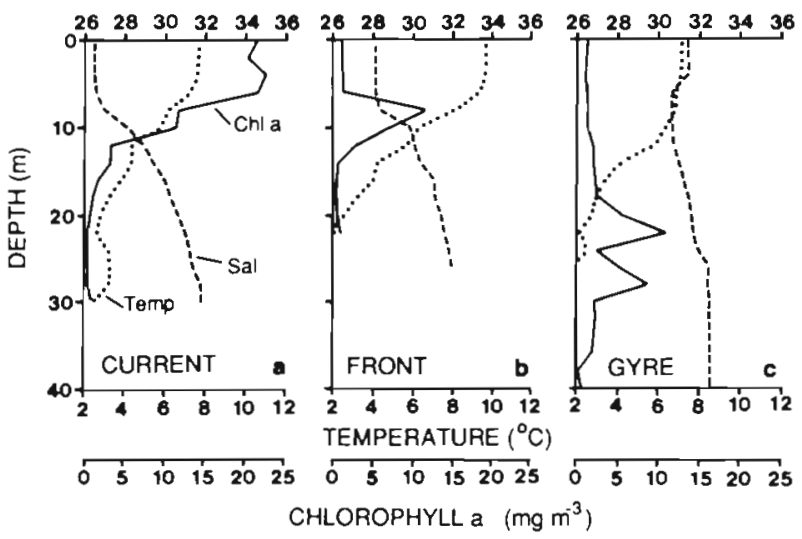

Fig. 3. Vertical profiles of salinity, temperature and chl a concentration in the surface layer of (a) the Gaspé current

(b) the front and (c) the Anticosti gyre, in early June 1985

Horizontally, salinity at $5 \mathrm{~m}$ proved a more useful descriptor of the frontal structure than the less conservative parameter temperature (Fig. 4). In early June 1985, the sampling transect started in the Anticosti gyre (salinity $>29.5$ ) then cut across the salinity front to reach the diluted waters of the Gaspé current (salinity $<27$ ) and finally back to the front (Fig. 4b). Surface $\left(3 \mathrm{~m}\right.$ ) concentration of chl a was high (15 to $35 \mathrm{mg} \mathrm{m}^{-3}$ ) in the Gaspé current, negatively correlated to salinity in the front, and low $\left(<0.5 \mathrm{mg} \mathrm{m}^{-3}\right)$ in the Anticosti gyre where phytoplankton biomass was distributed deeper than $3 \mathrm{~m}$ (Fig. 4c).

The cross-frontal distribution of copepod immature stages in the 0 to $25 \mathrm{~m}$ depth layer paralleled the distribution of near-surface chlorophyll (Fig. 4). The den-

Fig. 4. Cross-frontal distribution of temperature and salinity at $5 \mathrm{~m}$, chl a concentration at $3 \mathrm{~m}$, and relative abundance (see 'Materials and methods') of copepod developmental stages in the 0 to $25 \mathrm{~m}$ depth layer along the cross-frontal transect sampled from $07: 00 \mathrm{~h}$ on 3 June to $07: 00 \mathrm{~h}$ on 4 June 1985 . Distance is the distance travelled by the ship relative to the water. Copepod abundance given for 37 of the 360 stations sampled. Heavy horizontal bar represents darkness

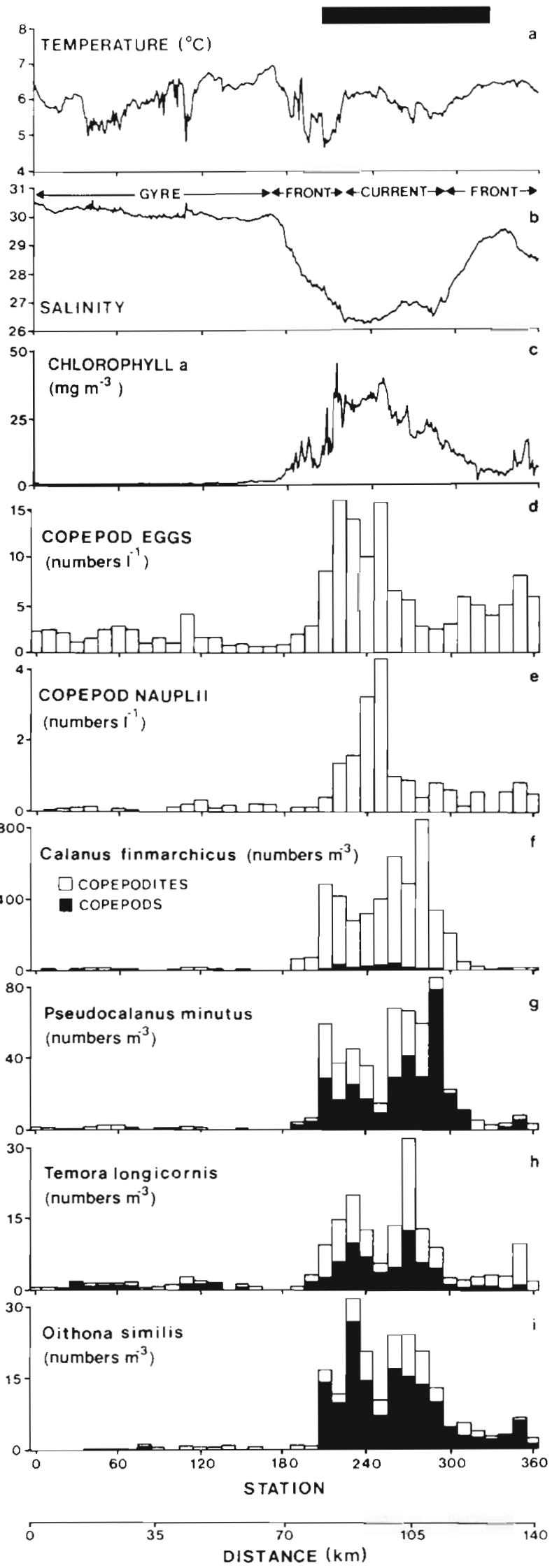


sity of copepod eggs and nauplii was low in the gyre, increased in the front and reached maximum values in the Gaspé current (Fig. 4d, e). Copepodites and adults of the main copepod species were abundant in night samples which were taken in the Gaspé current but not in daytime samples taken in the gyre (Fig. $4 \mathrm{f}$ to i). The density of all 5 copepod species in the surface layer ( 0 to $25 \mathrm{~m}$ ) peaked soon after sunset and again 1 or $2 \mathrm{~h}$ before dawn.

\section{Ichthyoplankton composition, length distribution, and feeding}

The ichthyoplankton assemblage was dominated by the larvae of sand lance and capelin, 2 coastal or estuarine spawners that produce demersal adherent eggs (Table 2). Sand lance prevailed in early June 1985 and capelin in early June and July 1986. The 2 species were captured primarily in the Gaspé current. Larvae of the ovoviviparous redfish Sebastes sp. were always present in considerable numbers. In early June 1985, Arctic shanny Stichaeus punctatus was sufficiently abundant to justify analyzing its distribution. The latter 2 species tended to be more abundant in the Anticosti gyre than the current (Table 2).
Sand lance were represented by a mixture of yolksac larvae and post-yolk-sac larvae in early June 1985 and primarily by post-yolk-sac larvae in early June and July 1986 (Fig. 5a to c). Only a small fraction of the capelin were yolk-sac larvae (Fig. 5d to f). Post-yolksac larvae of capelin in the range 13 to $25 \mathrm{~mm}$ formed a distinct cohort in early June 1985 and July 1986. Large pre-metamorphosis capelin were captured in early June of both years (1985: average length $=43.4$ $\mathrm{mm}, \mathrm{n}=25 ; 1986$ : average length $=36.9 \mathrm{~mm}, \mathrm{n}=30$; not shown on Fig. 5). The length-frequency distribution of redfish larvae always presented a single mode (Fig. $5 \mathrm{~g}$ to $\mathrm{i}$ ). Redfish larvae are extruded from the female at a length of about $6 \mathrm{~mm}$ with pigmented eyes and a well-developed mouth (Fahay 1983), after the yolk has been absorbed (Leim \& Scott 1966, p. 340). Based on their small length and the presence of yolksac remnants in some of them, the larvae captured in June 1985 and 1986 (modal length of 7.5 and $6.5 \mathrm{~mm}$ respectively) were recently spawned (Fig. $5 g, h$ ). The Arctic shanny formed a single cohort of post-yolk-sac larvae (Fig. 5j). This species is relatively large at hatching (9 to $12 \mathrm{~mm}$; Drolet et al. 1991) and the 13 to $14 \mathrm{~mm}$ larvae captured in June 1985 had probably only recently lost their yolk reserves.

The larvae of capelin, sand lance, redfish and Arctic shanny preyed primarily on copepod eggs and nauplii

Table 2. Number of fish larvae captured in 1985 and 1986 by period and species in the Anticosti gyre (salinity at $5 \mathrm{~m}>29.5$ ) and the Gaspé current including the front (salinity at $5 \mathrm{~m}<29.5$ )

\begin{tabular}{|c|c|c|c|c|c|c|c|}
\hline \multirow[t]{2}{*}{ Species } & \multirow[t]{2}{*}{ Common name } & \multicolumn{2}{|c|}{ 3-4 June 1985} & \multicolumn{2}{|c|}{ 3-4 June 1986} & \multicolumn{2}{|c|}{$10-12$ July 1986} \\
\hline & & Gyre & Current & Gyre & Current & Gyгe & Current \\
\hline Ammodytes sp. & Sand lance & 901 & 9910 & 390 & 1318 & 42 & 46 \\
\hline Mallotus villosus & Capelin & 13 & 2087 & 63 & 5060 & 201 & 13615 \\
\hline Sebastes sp. & Redfish & 1102 & 306 & 81 & 122 & 983 & 584 \\
\hline Stichaeus punctatus & Arctic shanny & 229 & 38 & 33 & 22 & 0 & 1 \\
\hline Hippoglossoides platessoides & American plaice & 17 & 3 & 0 & 13 & 0 & 0 \\
\hline Ulvaria subbifurcata & Radiated shanny & 0 & 17 & 0 & 11 & 9 & 34 \\
\hline Pseudopleuronectes americanus & Winter flounder & 0 & 15 & 0 & 5 & 0 & 247 \\
\hline Clupea harengus harengus & Atlantic herring & 0 & 10 & 0 & 31 & 0 & 10 \\
\hline Myoxocephalus scorpius & Shorthorn sculpin & 4 & 1 & 0 & 0 & 0 & 0 \\
\hline Enchelyopus cimbrius & Fourbeard rockling & 0 & 4 & 3 & 19 & 7 & 11 \\
\hline Aspidophoroides monopterygius & Alligatorfish & 1 & 2 & 4 & 0 & 0 & 0 \\
\hline Gadus morhua & Atlantic cod & 2 & 0 & 0 & 6 & 1 & 5 \\
\hline Pholis gunnellus & Rock gunnel & 1 & 0 & 3 & 5 & 0 & 0 \\
\hline Lumpenus lampretaeformis & Lumpfish & 0 & 1 & 5 & 1 & 0 & 7 \\
\hline Cyclopterus lumpus & Lumpfish & 0 & 1 & 0 & 0 & 0 & 0 \\
\hline Lumpenus maculatus & Daubed shanny & 0 & 0 & 4 & 3 & 0 & 0 \\
\hline Liopsetta putnami & Smooth flounder & 0 & 0 & 0 & 2 & 0 & 0 \\
\hline Scomber scombrus & Atlantic mackerel & 0 & 0 & 1 & 1 & 1 & 0 \\
\hline Gymnocanthus tricuspis & Arctic staghorn sculpin & 0 & 0 & 1 & 0 & 0 & 0 \\
\hline Agonus decagonus & Atlantic sea poacher & 0 & 0 & 1 & 0 & 0 & 0 \\
\hline Liparis sp. & Seasnail & 0 & 0 & 0 & 0 & 0 & 18 \\
\hline Total & & 2270 & 12395 & 589 & 6619 & 124 & 14578 \\
\hline Number of species & & 9 & 13 & 12 & 15 & 7 & 11 \\
\hline
\end{tabular}




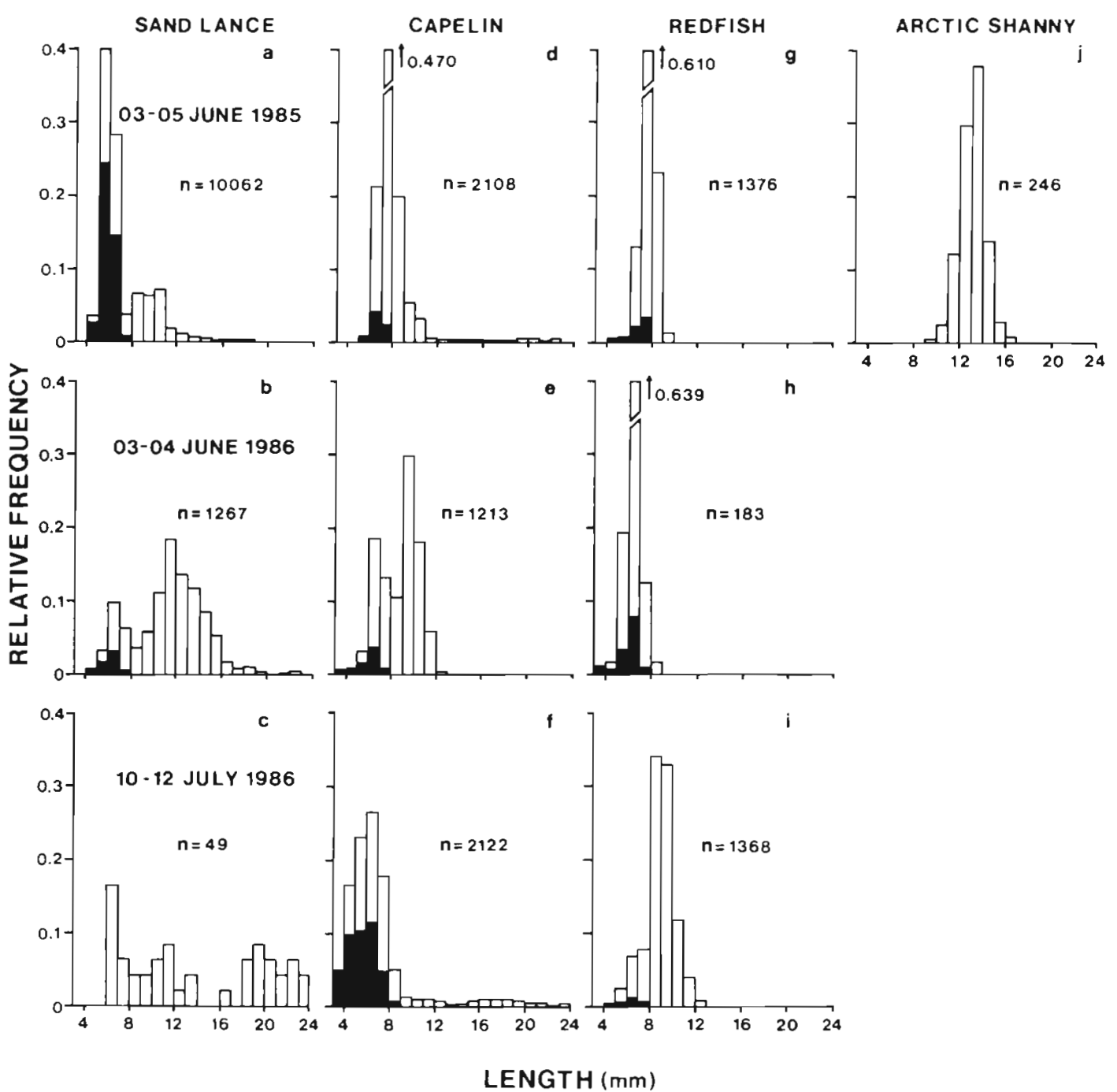

Fig. 5. Length-frequency distribution of the yolk-sac (black histograms) and post-yolk-sac (open histograms) stages of the main fish species by sampling periods in 1985 and 1986. n: number of larvae measured

(Table 3). The prey field shifted from copepod eggs to nauplii as mouthgap increased with increasing length, except in the large Arctic shanny, which preyed primarily on nauplii. Redfish larvae specialized on the large eggs (ca $140 \mu \mathrm{m}$ ) of Calanus sp. The diet of postyolk-sac larvae of capelin and Arctic shanny included copepodites and small adult copepods.

In June 1985, the Anticosti gyre was sampled during the day while the Gaspé current and the front were sampled at night (Fig. 4). For a given length class, sand lance larvae tended to feed less at night in the Gaspé current than in daytime in the gyre (Table 3). This more likely reflected a decrease in foraging activity in the dark than a difference in food availability between the 2 hydrographic regions. Feeding incidence was always high in redfish and Arctic shanny, and differed little between the Gaspé current (night) and the Anti- costi gyre (day), indicating that foraging efficiency was comparable between the 2 hydrographic regions (Table 3). Very few capelin larvae were captured in the gyre in June 1985 (see following section) and feeding incidence could not be compared between night and day or between the 2 hydrographic regions (Table 3 ).

Notwithstanding variations related to length, daynight effects or region of capture, redfish and Arctic shanny appeared more efficient predators than capelin and sand lance: feeding incidence and the average number of prey in the gut remained low in first-feeding $(<10 \mathrm{~mm}$ ) capelin and sand lance, but were invariably high in redfish and Arctic shanny of all sizes (Table 3). On average, redfish larvae captured larger prey than capelin or sand lance larvae of comparable length. The gut of virtually all Arctic shanny contained remarkably high numbers of large prey. 
Table 3. Percent composition of diet by species and length classes (mm), and feeding statistics in daytime (D) and at night (N), for larvae captured on 3 to 5 June 1985. The percentage of larvae feeding, the average number of prey in non-empty gut, the number of larvae analyzed, the average width of the prey and the percentage of larvae with yolk-sac are given. Note that no capelin larvae were captured in daytime

\begin{tabular}{|c|c|c|c|c|c|c|c|c|c|c|c|c|c|c|}
\hline & \multicolumn{4}{|c|}{ Capelin } & \multicolumn{4}{|c|}{ Sand lance } & \multicolumn{3}{|c|}{ Redfish } & \multicolumn{3}{|c|}{ Arctic shanny } \\
\hline & $<7$ & $7-9$ & $9-12$ & $>12$ & $<6$ & $6-8$ & $8-10$ & $>10$ & $<7$ & $7-8$ & $>8$ & $<13$ & $13-14$ & $4>14$ \\
\hline Copepod eggs & 29 & 23 & 17 & 12 & 0 & 33 & 21 & 13 & 69 & 72 & 43 & 7 & 8 & 8 \\
\hline Copepod nauplii & 35 & 46 & 49 & 74 & 0 & 56 & 79 & 84 & 27 & 27 & 57 & 78 & 74 & 75 \\
\hline Copepodites \& copepods & 0 & 1 & 4 & 6 & 0 & 0 & 0 & 0 & 0 & $<1$ & 0 & 9 & 13 & 12 \\
\hline Cladocerans & 0 & $<1$ & $<1$ & 0 & 0 & 0 & 0 & 0 & 0 & 0 & 0 & 1 & 1 & 1 \\
\hline Mollusk larvae & 0 & 0 & 0 & 0 & 0 & 0 & 0 & 2 & 4 & $<1$ & 0 & $<1$ & $<1$ & $<1$ \\
\hline Others ${ }^{\circ}$ & 12 & 9 & 17 & 2 & 0 & 0 & 0 & 1 & 0 & $<1$ & 0 & 2 & 2 & 3 \\
\hline Unidentified & 24 & 21 & 13 & 6 & 0 & 11 & 3 & 0 & 0 & 0 & 0 & 2 & 2 & 3 \\
\hline \multirow[t]{2}{*}{ Percent feeding } & - & - & - & - & 0 & 56 & 79 & 79 & 75 & 69 & 89 & 100 & 100 & 100 \\
\hline & 18 & 30 & 32 & 36 & 0 & 6 & 18 & 49 & 75 & 65 & 50 & 95 & 100 & 80 \\
\hline \multirow{2}{*}{ Number of prey } & - & - & - & - & 0 & 1.4 & 1.5 & 3.0 & 4.6 & 4.8 & 6.5 & 15.6 & 18.9 & 25.2 \\
\hline & 1.2 & 1.4 & 1.6 & 13.6 & 0 & 1.0 & 2.0 & 2.2 & 3.6 & 5.5 & 1.0 & 6.6 & 5.1 & 9.0 \\
\hline \multirow[t]{2}{*}{ Number of larvae } & 0 & 0 & 0 & 0 & 1 & 9 & 19 & 34 & 12 & 64 & 28 & 77 & 91 & 44 \\
\hline & 78 & 306 & 92 & 21 & 55 & 47 & 44 & 35 & 12 & 26 & 2 & 22 & 7 & 5 \\
\hline Width of prey $(\mu \mathrm{m})$ & 75 & 93 & 103 & 131 & - & 76 & 87 & 99 & 117 & 115 & 122 & 182 & 144 & 135 \\
\hline Percent yolk-sac & 21 & 5 & 1 & 0 & 59 & 41 & 0 & 0 & 12 & 6 & 0 & 0 & 0 & 0 \\
\hline
\end{tabular}

\section{Cross-frontal distribution of fish larvae and their prey}

Particles in the size range 203 to $512 \mu \mathrm{m}$ ESD comprised some nauplii, but mostly copepodites and small copepods, and hence reflected the availability of potential prey to fish post-yolk-sac larvae which feed on increasingly large developmental stages of copepods. In early June 1985, the density of particles 203 to $512 \mu \mathrm{m}$ ESD in the 0 to $25 \mathrm{~m}$ depth layer was 1 order of magnitude greater in the Gaspé current than in the Anticosti gyre (Fig. 6b) and its cross-frontal distribution followed that of copepod eggs and nauplii (Fig. 4). Particle density decreased rapidly across the salinity front itself (Fig. 6b).

In early June 1985, sand lance and capelin larvae were abundant in the Gaspé current (Fig. 6c, d). Few sand lance and almost no capelin were captured in the more saline waters ( $>29.5$ ) of the Anticosti gyre. In contrast to particles, the distribution of the 2 species extended into the salinity front (Fig. 6c, d). Larval redfish and Arctic shanny were more abundant in the Anticosti gyre than the Gaspé current, with a tendency to accumulate at the offshore edge of the salinity front (Fig. 6e, f). Few redfish and almost no Arctic shanny were collected in the salinity front or the Gaspé current.
The cross-frontal distribution of salinity, chlorophyll and fish larvae in 1986 generally confirmed the picture for 1985 (Figs. 7 \& 8). In early June 1986, phytoplankton biomass at $3 \mathrm{~m}$ was high in the Gaspé current, maximum at the inshore boundary of the front, intermediate in the front itself, and uniformly low in the Anticosti gyre (Fig. $7 \mathrm{c}$ ). The relatively small capelin larvae and post-yolk-sac larvae (modal lengths of 6.5 and $9.5 \mathrm{~mm}$ respectively; Fig. 5e) were abundant nearshore in the current and virtually absent from the gyre (Fig. 7 d). The relatively large post-yolk-sac larvae of sand lance (modal length $=11.5 \mathrm{~mm}$; Fig. $5 \mathrm{~b}$ ) were abundant in the current and the front, and low densities were observed in the gyre (Fig. 7 e). Small redfish

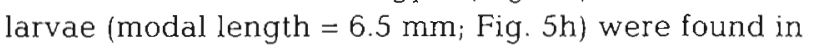
all regions and their distribution appeared unrelated to hydrography (Fig. 7f).

In July 1986, high phytoplankton biomass at $3 \mathrm{~m}$ was again associated with the diluted waters of the Gaspé current (Fig. 8c). Again, small capelin larvae (modal length $=6.5 \mathrm{~mm}$; Fig. $5 f$ ) were distributed primarily in the diluted waters of the Gaspé current (Fig. 8d). Redfish larvae were relatively abundant in all regions except the nearshore zone (Fig. 8e). The distribution of the few post-yolk-sac sand lance larvae (average length $=14.9 \mathrm{~mm}$ ) captured in July 


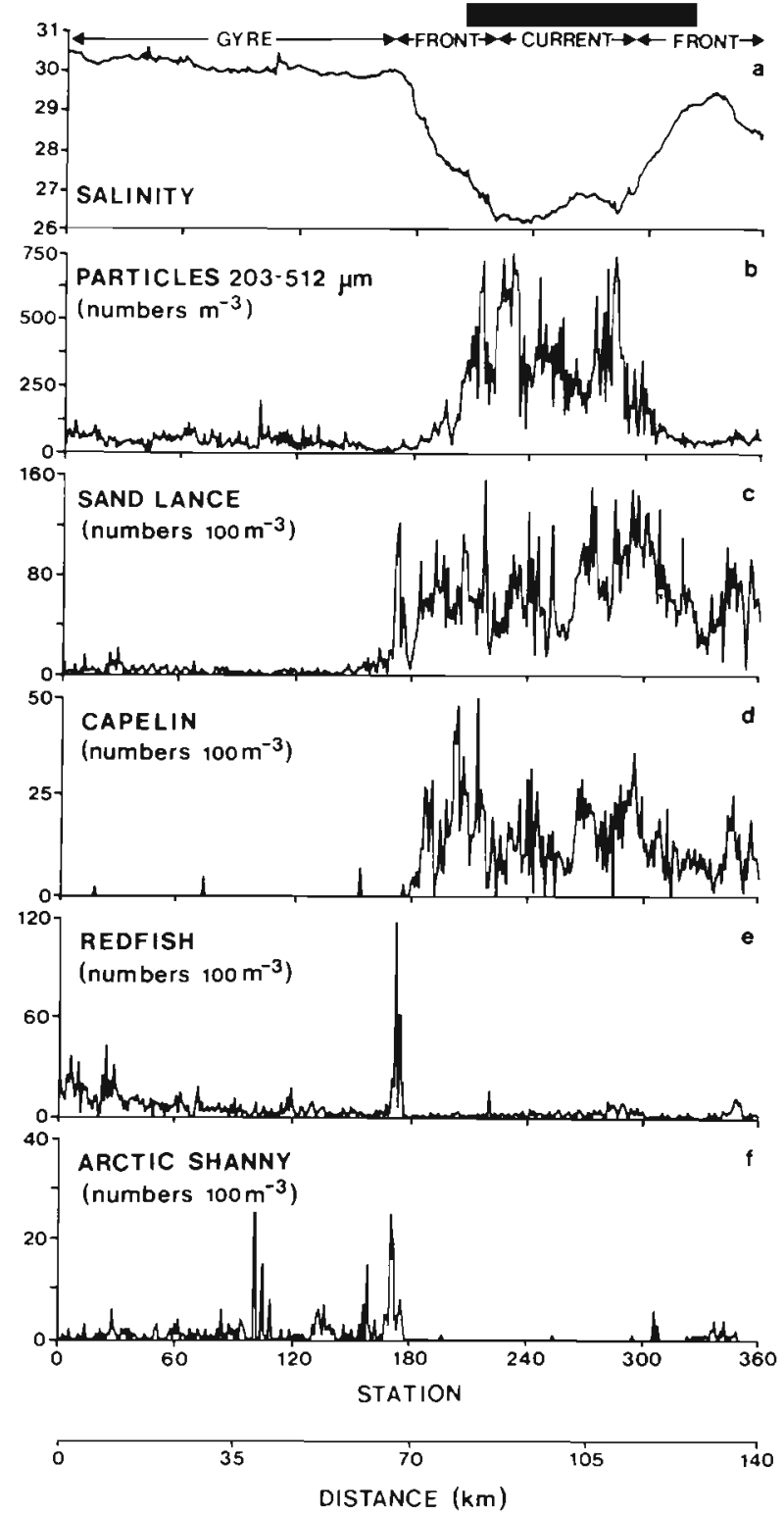

Fig. 6. Cross-frontal distribution of salinity at $5 \mathrm{~m}$, particles (size range 203 to $512 \mu \mathrm{m}$ equivalent spherical diameter) and larval fish density in the 0 to $25 \mathrm{~m}$ depth layer along the crossfrontal transect sampled from $07: 00 \mathrm{~h}$ on 3 June to $07: 00 \mathrm{~h}$ on 4 June 1985 (360 samples). Distance represents the distance travelled by the ship relative to the water. Heavy horizontal bar represents darkness

1986 did not appear limited to any of the 3 hydrographic regions (Fig. 8f).

A vertical section was sampled in July 1986 to verify that the cross-frontal distributions observed with the high-resolution sampling of the 0 to $25 \mathrm{~m}$ layer did not simply reflect differences in the vertical distribution of the organisms between the Gaspé current and the Anticosti gyre (e.g. a deeper distribution of the larvae

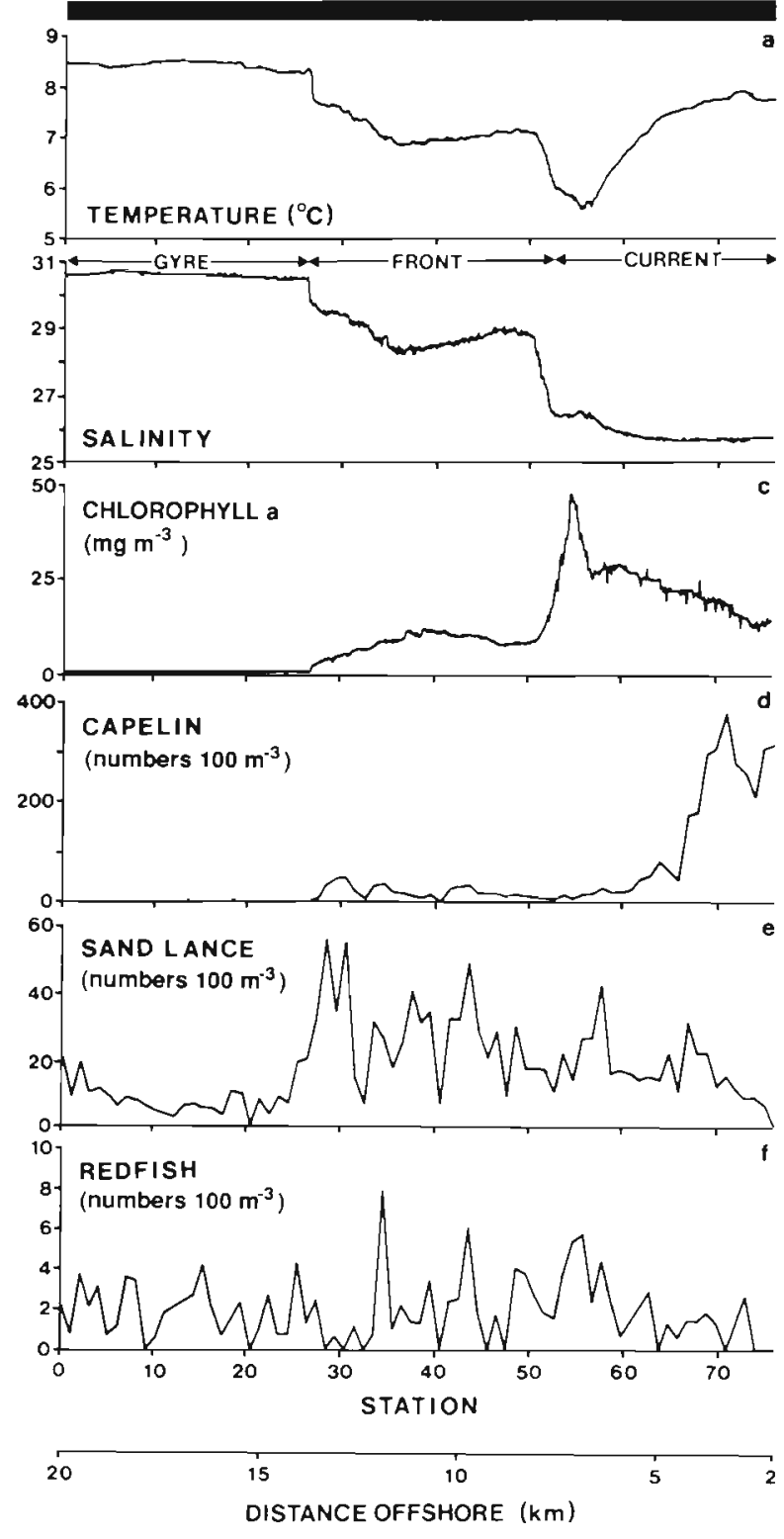

Fig. 7. Cross-frontal distribution of temperature and salinity at $5 \mathrm{~m}$, chl a concentration at $3 \mathrm{~m}$, and larval fish densities in the 0 to $25 \mathrm{~m}$ depth layer along the north-south cross-frontal transect sampled from 22:14 h on 3 June to $03: 43$ h on 4 June 1986

(76 samples). Heavy horizontal bar represents darkness

and their food in the Anticosti gyre). The results confirmed the close association between high concentrations of particles suitable for larval fish feeding and the diluted waters of the Gaspé jet current (Fig. 9). The density of particles 203 to $512 \mu \mathrm{m}$ ESD was 10 to 20 times greater in the salinity front and the surface waters of the jet current than at any depth in the gyre (Fig. 9b). Isopleths of particle density generally paralleled the isohalines (Fig. 9a, b). Microscopic examination of the plankton retained by the $80 \mu \mathrm{m}$ mesh of the 
rigid codend confirmed that the distribution of particles in the size range 203 to $512 \mu \mathrm{m}$ ESD (Fig. 9b) mirrored the abundance of copepod eggs and nauplii, the food of fish larvae (Fig. 10a, b).

The 850 to $2000 \mu \mathrm{m}$ size-fraction of the plankton, which was made up almost exclusively of copepodites and adults of Calanus finmarchicus, Pseudocalanus minutus, Temora longicornis, and Oithona similis, formed distinct patches distributed in the surface waters of the gyre and the saline waters underlying the

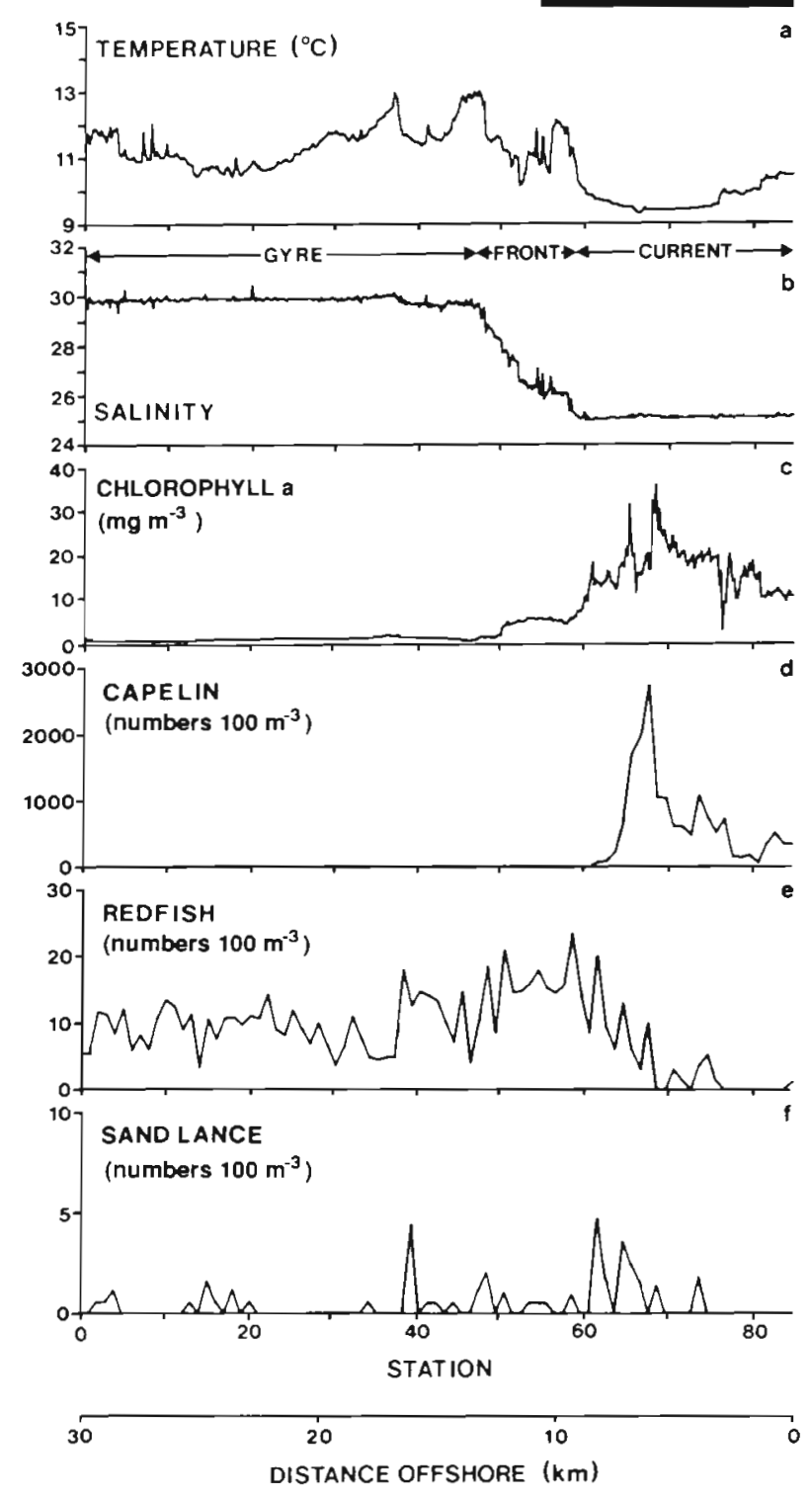

Fig. 8. Cross-frontal distribution of temperature and salinity at $5 \mathrm{~m}, \mathrm{chl}$ a concentration at $3 \mathrm{~m}$, and larval fish densities in the 0 to $25 \mathrm{~m}$ depth layer along the north-south cross-frontal transect sampled from $17: 14$ to $23: 16 \mathrm{~h}$ on 12 July 1986 (85 samples). Heavy horizontal bar represents darkness

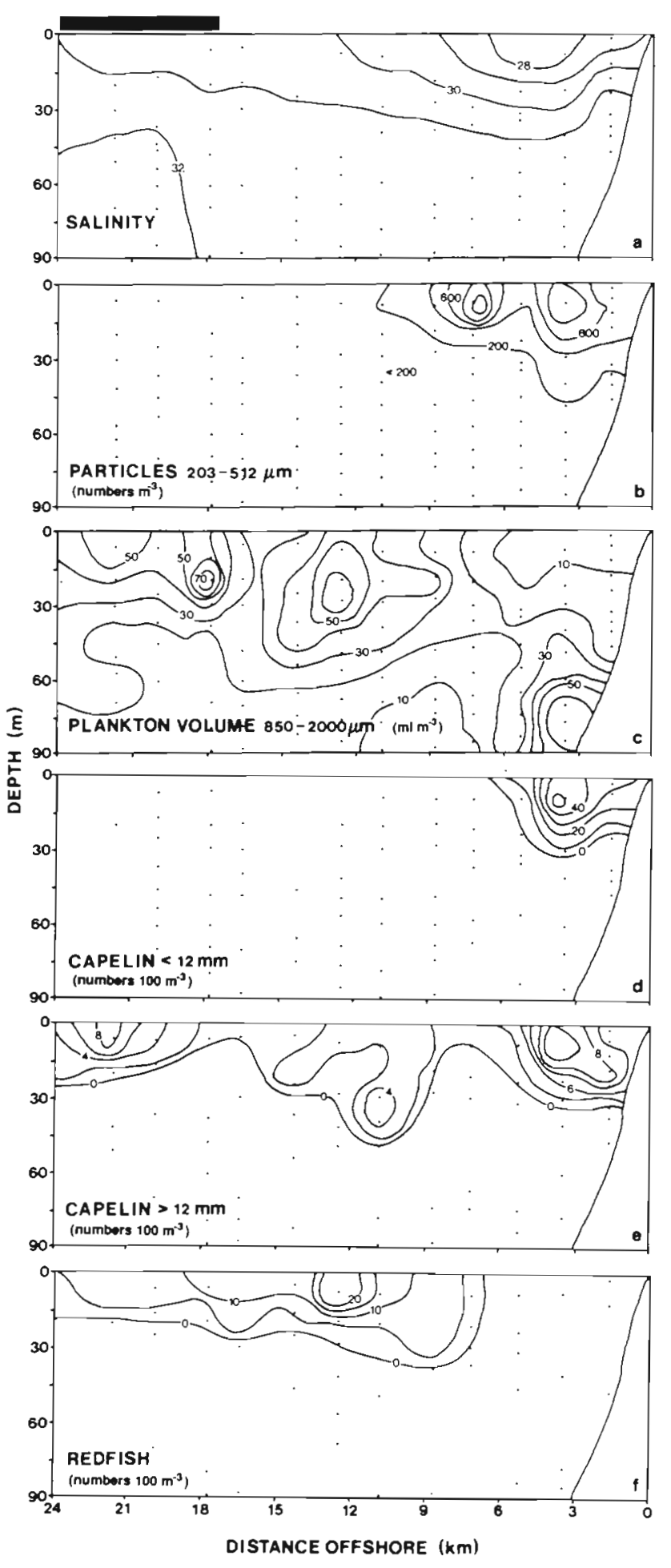

Fig. 9. Vertical cross-sections of salinity, particle density (size range 203 to $512 \mu \mathrm{m}$ equivalent spherical diameter), zooplankton displacement volume (size range 850 to $2000 \mu \mathrm{m}$ ), and larval fish density along the south-north cross-frontal transect sampled from $10: 05 \mathrm{~h}$ to $00: 53 \mathrm{~h}$ on 11 July 1986 ( $n=108$ samples at 12 stations; dots indicate depth of samples). Heavy horizontal bar represents darkness 
Quspé current (Fig. 9c). Day-night differences in the vertical position of the patches reflected diel migrations by the copepods. Copepodites abundance peaked in the salinity front (Fig. 10c) while copepods were rather evenly distributed over the frontal region (Fig. 10d).

Small capelin larvae $(<12 \mathrm{~mm})$ were found exclusiwely in the less saline waters of the current but the distribution of larger post-yolk-sac larvae (>12 mm) extended across the salinity front and into the gyre (Firy. 9d, e). Redfish larvae were distributed in the surface waters of the gyre and again showed some tendency to accumulate on the gyre side of the salinity front (Fig. 9f). Both larval fish species were restricted primarily to the 0 to $30 \mathrm{~m}$ depth layer and neither exhibited strong differences in vertical distribution between day and night (Fig. 9d to f).

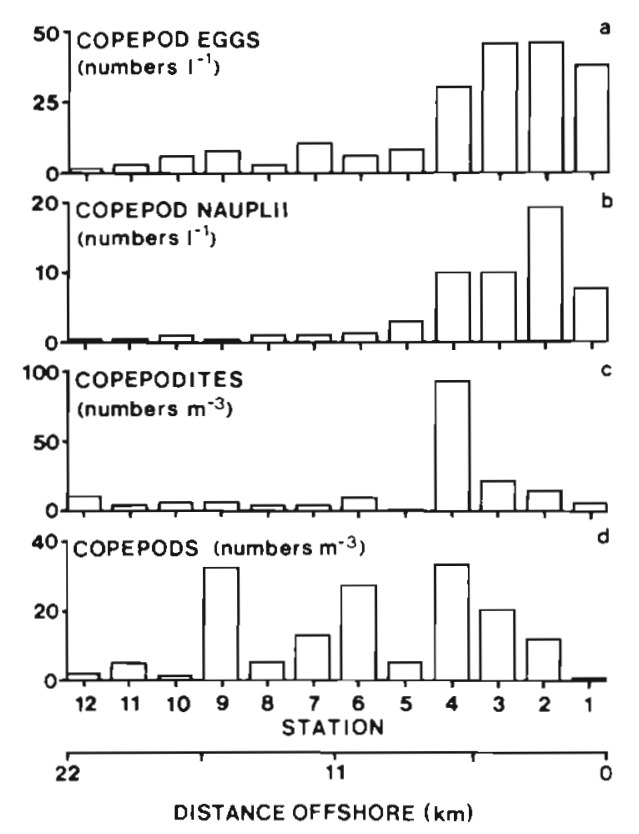

Fig. 10. Density of copepod eggs, nauplii, copepodites and ad Ins in samples from the 0 to $10 \mathrm{~m}$ depth layer of the southnor h cross-frontal vertical section sampled from 10:05 to 00:53 h on 11 July 1986 (see Fig. 9)

\section{Orltogenetic migration of fish larvae across the front}

The newly hatched larvae of estuarine spawners were restricted to the Gaspé current whereas older pas:-yolk-sac larvae were more evenly distributed over the frontal region, suggesting some cross-frontal dispersion as development proceeded. A good example of this ontogenetic cross-frontal migration is given by sand lance larvae in early June 1985 (Fig. 11). Yolk-

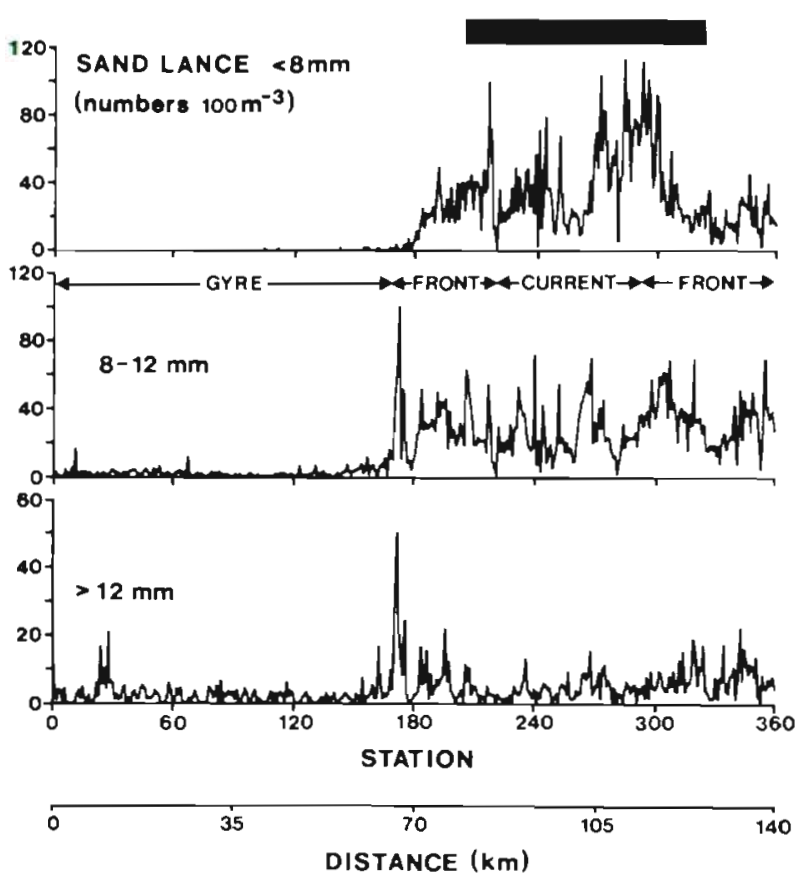

Fig. 11. Ammodytes sp. Cross-frontal distribution of sand lance larvae by length classes along the cross-frontal transect sampled from $07: 00 \mathrm{~h}$ on 3 June to $07: 00 \mathrm{~h}$ on 4 June 1985 (360 samples). Distance represents the distance travelled by the ship relative to the water. Heavy horizontal bar represents darkness

sac larvae $(<8 \mathrm{~mm})$ were found almost exclusively in the Gaspé current (Fig. 11, top graph). With increasing size, the post-yolk-sac larvae became more evenly distributed over the frontal region, with a tendency to accumulate at the limit between the gyre and the salinity front (Fig. 11, middle and lower graphs). Ontogenetic cross-frontal dispersion of sand lance and capelin larvae was also observed during other sampling periods (e.g. Fig. 9d, e).

\section{DISCUSSION}

\section{Hydrography, export production, and copepod reproduction}

Large cells, in particular diatoms which are easily exported to herbivores, are the first link in the short plankton food chain. In the frontal region formed by the Gaspé coastal jet current and the Anticosti gyre, export production took place primarily in the stratified surface waters of the jet current where neither nutrients nor light limits the production of diatoms in spring and early summer (Sevigny et al. 1979, Levasseur et al. in press). Within the Gaspé current the build-up of high chlorophyll concentrations (up to 
$35 \mathrm{mg} \mathrm{chl} \mathrm{a} \mathrm{m}^{-3}$ ) reflected the intense production and accumulation of diatoms which, because of their size, represent the bulk of the microalgal biomass. Large cells were also present in the sub-surface chlorophyll maximum of the Anticosti gyre, indicating that some export production was available to herbivores at depth. Yet, the overall abundance and concentration of diatoms were several times less in the gyre than in the Gaspé current.

In June 1985, collections in the surface (0 to $25 \mathrm{~m}$ ) layer suggested that both the immature and adult stages of copepods were distributed primarily in the Gaspé current (e.g. Fig. 4). However, the scarcity of adult copepods at that time in the surface waters of the gyre probably reflected some diel vertical migration, as the gyre was sampled in daytime and the current at night. The cross-frontal vertical section using the multiple net sampler in July 1986 confirmed that large copepods ( 850 to $2000 \mu \mathrm{m}$ zooplankton fraction) were widely distributed over the area sampled. The immature stages were distributed primarily in the diluted waters of the Gaspé current, above the cold $\left(<0^{\circ} \mathrm{C}\right)$ intermediate layer. Thus, copepod reproduction (as denoted by the ratio of eggs and nauplii abundance to adult abundance) was associated with higher concentrations of diatoms in the surface waters of the Gaspé current.

Egg production in copepods can be fueled by lipid reserves, the immediate food supply, or a combination of these 2 sources of energy (Ohman 1987, Runge 1988, Hirche 1989). In all cases, egg production is accelerated by feeding and increases asymptotically with phytoplankton concentration (Conover 1965, Mullin 1988, Hirche 1989). Based on direct measurements of egg production, Kiørboe \& Johansen (1986) and Kiørboe et al. (1988) reported that copepod reproduction was food-limited at chlorophyll concentrations $<1.6 \mathrm{mg} \mathrm{m}^{-3}$. Limitation of copepod reproduction has been observed at chl a concentrations as high as $6 \mathrm{mg}$ $\mathrm{m}^{-3}$ (Richardson 1985). Thus, the low concentrations of chlorophyll in the surface waters of the Anticosti gyre $\left(<1.0 \mathrm{mg} \mathrm{m}^{-3}\right.$ ) were probably not sufficient to fuel copepod reproduction, and the limited production of eggs observed in the gyre presumably depended on the exploitation of the deep chlorophyll maximum at 20 to $27 \mathrm{~m}$.

Despite this deep chlorophyll maximum, copepod reproduction in early June and July remained much less intense in the gyre than in the Gaspé current. where eggs and nauplii were 1 order of magnitude more abundant. Thus, in spring and summer, export production sufficient to sustain intense copepod reproduction and the massive production of larval fish food existed primarily in the Gaspé current. This is generally consistent with the conclusion of Sevigny et al.
(1979) that the front separates 2 semi-enclosed pelagic ecosystems, 'the Gaspé current characterized by continuous high summer production, large-celled diatoms small copepods, and fish larvae; and the Anticost gyre characterized by nutrient-limited phytoplankton growth, small flagellates, large copepod species, euphausuids, and decapod larvae'.

\section{Spawning strategies and the co-distribution of fish larvae and their food in the frontal region}

A long-standing view embedded in the theory of the tropho-dynamic control of larval fish survival is that the spawning strategies of fish are adapted to local hydrography to favor the coincidence in time and space of the first-feeding larvae and their prey (Hjort 1914, 1926, Harden-Jones 1968, Cushing 1972, Leiby 1984). Sinclair (1988) put forward the alternative hypothesis that the primary role of hydrography is to preserve the genetic integrity of the population by limiting the dispersion of the planktonic larvae.

In the present study, the close association of firstfeeding capelin with the diatom bloom and the superabundance of copepod prey in the Gaspé current can be traced back to the peculiar spawning and dispersion strategy of the species. Capelin spawn adherent eggs on sandy intertidal flats (see Fortier et al. 1987 for a review). Spawning is concentrated in the upper estuary of the St. Lawrence (Parent \& Brunel 1976), some $350 \mathrm{~km}$ upstream of the present sampling area. From late May to late June, the larvae emerge from the intertidal flats at night (Fortier et al. 1987) and are advected seaward by the estuarine surface flow that later forms the Gaspé current (Jacquaz et al. 1977. Fortier \& Leggett 1982, 1983, 1985). A Lagrangian study of larval capelin drift suggests that the duration of their transit from the upper estuary to the area sampled in the present study is approximately 2 to $3 \mathrm{wk}$ (Fortier \& Leggett 1985). Thus, capelin spawning time and location in relation to the dynamical but predictable estuarine circulation result, after 2 to $3 \mathrm{wk}$ of drift over $350 \mathrm{~km}$, in a remarkable spatio-temporal coincidence between the first-feeding larvae and high concentrations of the copepod eggs and nauplii on which they prey. The yolk-sac larvae are seeded in the very same nutrient-rich water mass that will stabilize in the Gaspé current to trigger the intense diatom bloom that will in turn fuel copepod reproduction.

The spawning grounds of sand lance in the St. Lawrence are not known, but the similarity between the larval crcss-frontal distribution of this species and that of capelin indicates an estuarine origin and a very similar spawning and dispersion strategy. Runge \& Simard (1990) proposed that larval euphausiids pro- 
duced in the lower estuary are also transported to the southern Gulf of St. Lawrence by the productive waters of the Gaspé current. The upstream migration of adult euphausiids to the head of the Laurentian channel would result from their occupation of the deep landward flow rather than from an active spawning migration as in fish.

As they increased in size, some capelin and sand lance post-yolk-sac larvae advected by the Gaspé current were trapped in the front and transported across to the Anticosti gyre. Entrapment in the front and cross-frontal transport to the gyre are perhaps related to the sharp horizontal gradient in current speed between the jet current and the cyclonic gyre (Benoit et al. 1985, Levasseur et al. in press). Cross-frontal transport may also occur when large wavelike eddies (wavelength $=50 \mathrm{~km}$ ) form in the front following a disruption of the geostrophic balance (Tang 1980a, 1983) and then break off, entraining fish larvae and plankton into the gyre. The gyre is the known nursery area of juvenile capelin (Jacquaz et al. 1977), where they feed primarily on copepods (Vésin et al. 1981). Thus, the dispersion strategy of capelin (and presumably that of sand lance) favors the coincidence of the first-feeding larvae with high densities of prey in the Gaspé current and then the transfer of some of the post-yolk-sac larvae to their nursery grounds in the Anticosti gyre.

In addition to capelin and sand lance, several migratory fish with complex life strategies maintain stocks in the estuary and northwestern Gulf of St. Lawrence (see de Lafontaine 1990 for a review). In the upper reaches of the estuary, salinity fronts and stratification fronts play a particularly important role in limiting the seaward dispersion of the early planktonic stages of rainbow smelt Osmerus mordax, Atlantic tomcod Microgadus tomcod and Atlantic herring Clupea harengus (Able 1978, Ouellet \& Dodson 1985, Laprise \& Dodson 1989, Dodson et al. 1989, Fortier \& Gagné 1990). In all cases, the retention of the newly hatched larvae and their zooplankton prey above the frontal boundaries provided some trophic advantage to the first-feeding larvae (Fortier \& Leggett 1984, Dauvin \& Dodson 1990 , Fortier \& Gagné 1990, present study). The hypothesis that spawning times and locations are adapted at least in part to ensure the co-distribution of first-feeding larvae with high levels of export production and the reproduction of copepods or other prey organisms cannot be rejected for these species.

On the other hand, frontal boundaries are not totally efficient at trapping the larvae in their nursery areas. Some herring larvae are lost from the St. Lawrence estuary to the Gaspé current (Fortier \& Gagné 1990). Similarly, some capelin and sand lance post-yolk-sac larvae remained in the Gaspé current (Figs. 9 \& 11) and were probably entrained to the southern Gulf of
St. Lawrence instead of the Anticosti gyre. Whether these offspring return to the spawning grounds of the upper estuary as adults or are lost from the genetic pool of the estuarine populations as proposed by the member/vagrant hypothesis (Sinclair 1988) remains to be clarified.

The spawning strategies of other species obviously did not aim at dispersing the larvae in the hydrographic area of maximum export production. For example, recently spawned redfish larvae still bearing traces of yolk were found in the productive surface waters of the Gaspé current, but the reproduction effort of this species was rather concentrated in the less productive waters of the Anticosti gyre. The subsurface chlorophyll maximum observed in the gyre probably reflected the sinking of the spring bloom of diatoms that occurs in late April in the area (Sevigny et al. 1979). The spawning of redfish larvae apparently started soon after this spring bloom and continued throughout the summer period of production of their zooplankton prey, a reproduction strategy also observed in the Gulf of Maine (Sherman et al. 1984). Arctic shanny is a demersal spawner that lives in the coastal zone during the adult stage (Farwell et al. 1976). The close association of Arctic shanny larvae with the less productive waters of the gyre and their virtual absence from the Gaspé current suggested that they originated from the north coast of the NW Gulf (Fig. 1). Overall food availability to first-feeding and early post-yolk-sac larvae of redfish and Arctic shanny was at least 1 order of magnitude less in the gyre than in the adjacent Gaspé current.

Some redfish and sand lance larvae (as well as postyolk-sac larvae of capelin and sand lance) accumulated at the boundary between the front and the Anticosti gyre. A similar concentration of ichthyoplankton at the estuarine front of the Mississippi River plume (USA) has been explained by frontal convergence (Govoni et al. 1989, Grimes \& Finucane 1991). Whether feeding conditions for fish larvae were actually improved in the Mississipi plume front remained conjectural (Govoni \& Chester 1990, Grimes \& Finucane 1991). In the estuarine plume front studied here, export production is sporadically increased on the gyre side of the front during the summer months by the upwelling of nutrient- and diatom-rich waters from the base of the Gaspé current (Levasseur et al. in press). Although peak densities of larvae were sometime observed at the gyre-front boundary, the majority of larval redfish or Arctic shanny were distributed in the Anticosti gyre. This suggests that the accumulation of the larvae in this potentially productive boundary may have been accidental and did not reflect a particular adaptation of the spawning and early dispersion strategies to the frontal circulation. 


\section{Production regimes and reproductive tactics of marine fishes}

For fish larvae, the massive build-up of food (copepod eggs and nauplii) linked to export production in the Gaspé current represents an ecological vacuum (sensu Pianka 1970) that can be invaded with little or no intra- or interspecific competition taking place. Such ecological vacuums where food becomes superfluously abundant should favor $\mathrm{r}$ selected (i.e. opportunistic) species while environments where food is scarcer should favor K-selected species (Pianka 1970).

A comparison of the reproduction strategies of the species associated with the different production regimes of the Gaspé current and the Anticosti gyre supports these predictions. Capelin and sand lance in the productive surface waters of the current are typical $r$-strategists that produce large numbers of relatively small larvae with relatively poor foraging abilities. Redfish and Arctic shanny in the less productive waters of the Anticosti gyre are (relatively) more Kselected species that produce few and large offspring with good predatory skills. Based on the seasonal occurrence of the larvae in relation to the production of their copepod prey, Sherman et al. (1984) concluded as well that redfish are at the $\mathrm{K}$ end of the $\mathrm{r}-\mathrm{K}$ continuum found in marine fish while sand lance is the consummate r-strategist.

The hypothesis that the spawning strategies of fish in relation to circulation are adapted to disperse firstfeeding larvae in hydrographic areas where export production is maximum was supported for capelin and sand lance but not for redfish and Arctic shanny. We conclude that opportunistic species producing large numbers of small offspring with limited foraging skills (e.g. capelin, sand lance) depend on massive export production at hydrographic singularities for reproduction. Species producing fewer but larger and more competent larvae (e.g. redfish, Arctic shanny) can colonize less productive areas of the ocean.

Larger size at hatching clearly imparts better foraging skills to fish larvae (Miller et al. 1988) but also necessarily reduces the number of offspring that can be produced by a female (Duarte \& Alcaraz 1989). In the present study, the equilibrium reached by a given species in the trade-off between size at hatching and fecundity reflected the availability of copepod eggs and nauplii in the dispersion area of the first-feeding larvae. This suggests that the reproduction traits of marine fish species are determined to some extent by the level of export production prevailing in the dispersal area of their larvae.
Acknowledgements. The Natural Sciences and Engineering Research Council of Canada (NSERC) and the Québec Fonds pour la Formation de Chercheurs et l'Aide à la Recherche (FCAR) provided financial support. Special thanks to $E$. Bonneau, C. Dutil, G. Lobb and J. Pauze for their contribution at every phase of this study. Dr B. R. Heimdall identified the microalgae. M. Bolduc, D. Boudreau, S. Cantin, J.-Y. Couture, L. Girard, S. Gosselin, N. Hamel, P. Joly, R. Langis, S. Lévesque, M.-J. Martineau, J. Moisan, and S. Toutant assisted in the field or the laboratory. Dr J. A. Gagné, Institut Maurice Lamontagne, kindly supplied the satellite picture of the Gulf of St. Lawrence.

\section{LITERATURE CITED}

Able, K. W. (1978). Ichthyoplankton of the St. Lawrence estuary: composition, distribution, and abundance. J. Fish. Res. Bd Can. 35: 1518-1531

Benoît, J., El-Sabh, M. I., Tang, C. L. (1985). Structure and seasonal characteristics of the Gaspé current. J. geophys. Res. 90: 3225-3236

Boyd, C. M., Smith, S. L. (1983). Plankton, upwelling, and coastally trapped waves off Peru. Deep Sea Res. 30: $723-742$

Caron, D. A., Goldman, J. C., Andersen, O. K., Dennett, M. R. (1985). Nutrient cycling in a microflagellate food chain. II. Population dynamics and carbon cycling. Mar. Ecol. Prog. Ser. 24: 243-254

Chenoweth, S. B., Libby, D. A., Stephenson, R. L., Power, M. J. (1989). Origin and dispersion of larval herring (Clupea harengus) in coastal waters of Eastern Maine and Southwestern New Brunswick. Can. J. Fish. Aquat. Sci. 46: $624-632$

Conover, R. J. (1965). Notes on the molting cycle, development of sexual characters and sex ratio in Calanus hyperboreus. Crustaceana 8: 308-320

Cushing, D. H. (1972). The production cycle and the number of marine fish. Symp. zool. Soc. Lond. 29: 213-232

Cushing, D. H. (1989). A difference in structure between ecosystems in strongly stratified waters and in those that are only weakly stratified. J. Plankton Res. 11: 1-13

Dauvin, J.-C., Dodson, J. J. (1990). Relationship between feeding incidence and vertical and longitudinal distribution of rainbow smelt larvae (Osmerus mordax) in a turbid well-mixed estuary. Mar. Ecol. Prog. Ser. 60: 1-12

de Lafontaine, Y. (1990). Ichthyoplankton communities in the St. Lawrence estuary: composition and dynamics. In: ElSabh, M. I., Silverberg, N. (eds.) Oceanography of a largescale system: the St. Lawrence. Lecture notes on coastal and estuarine studies, Vol. 39. Springer-Verlag, New York, p. 321-343

de Lafontaine, Y., El-Sabh, M. I., Sinclair, M., Messieh, S. N., Lambert, J.-D. (1984). Structure océanographique et distribution spatio-temporelle d'oeufs et de larves de poissons dans l'estuaire maritime et la partie ouest du golfe Saint-Laurent. Sci. Tech. Eau 17: 43-50

Dodson, J. J., Dauvin, J.-C., Ingram, R. G., d'Anglejan, B. (1989). Abundance of larval rainbow smelt (Osmerus mor$d a x)$ in relation to the maximum turbidity zone and associated macroplanktonic fauna of the middle St. Lawrence estuary. Estuaries 12: 66-81

Drolet, R., Fortier, L., Ponton, D., Gilbert, M. (1991). Production of fish larvae and their prey in subarctic southeastern Hudson Bay. Mar. Ecol. Prog. Ser. 77: 105-118

Duarte, C. M., Alcaraz, M. (1989). To produce many small or 
few large eggs: a size-independent reproductive tactic of fish. Oecologia 80: 401-404

El-Sabh, M. I. (1976). Surface circulation patterns in the Gulf of St. Lawrence. J. Fish. Res. Bd Can. 33: 124-138

Fahay, M. P. (1983). Guide to the early stages of marine fishes occurring in the western North Atlantic Ocean, Cape Hatteras to the southern Scotian Shelf. J. NW Atl. Fish. Sci. 4: $1-423$

Farwell, M. K., Green, J. M., Pepper, V. A. (1976). Distribution and known life history of Stichaeus punctatus in the Northwest Atlantic. Copeia 3: 598-602

Forrester, W. D. (1964). A quantitative temperature-salinity study of the Gulf of St. Lawrence. Report 64-11, Bedford Inst. Oceanography, Dartmouth, N.S., Canada

Fortier, L., Gagné, J A. (1990). Larval herring dispersion. growth and survival in the St. Lawrence estuary: match/mismatch or membership/vagrancy? Can. J Fish. Aquat. Sci. 47: 1898-1912

Fortier, L., Leggett, W. C. (1982). Fickian transport and the dispersal of fish larvae in estuaries. Can. J. Fish. Aquat. Sci. 39: 1150-1163

Fortier, L., Leggett, W. C. (1983). Vertical migrations and transport of larval fish in a partially mixed estuary. Can. J. Fish. Aquat. Sci. 40: 1543-1555

Fortier, L., Leggett, W. C. (1984). Small-scale covariability in the abundance of fish larvae and their prey. Can. J. Fish. Aquat. Sci. 41: 502-512

Fortier, L., Leggett, W .C. (1985). A drift study of larval tish survival. Mar. Ecol. Prog. Ser. 25: 245-257

Fortier, L., Leggett, W. C., Gosselin, S. (1987). Patterns of larval emergence and their potential impact on stock differentiation in beach spawning capelin (Mallotus villosus). Can. J. Fish. Aquat. Sci. 44: 1326-1336

Goldman, J. C. (1988). Spatial and temporal discontinuities of biological-physical interactions in the World Ocean. In: Rothschild, B. J. (ed.) Towards a theory of biologicalphysical interactions in the World Ocean. Academic Publishers, Dordrecht, p. 273-296

Govoni, J. J., Chester, A. J. (1990). Diet comut position of larval Leiostomus xanthurus in and abohe Mississippi River plume. J. Plankton Res. 12: 819-830

Govoni, J. J., Hoss, D. E., Colby, D. R. (1989). The spatial distribution of larval fish about the Mississippi River plume. Limnol. Oceanogr. 34: 178-187

Grimes, C. B., Finucane, J. H. (1991). Spatial distribution and abundance of larval and juvenile fish, chlorophyll and macrozooplankton around the Mississippi River discharge plume, and the role of the plume in fish recruitment. Mar. Ecol. Prog Ser. 75: 109-119

Harden-Jones, F. R. (1968). Fish migrations. Arnold, London

Hirche, H.-J. (1989). Egg production of the Arctic copepod Calanus glacialis: laboratory experiments. Mar. Biol. 103: $311-318$

Hjort, J. (1914). Fluctuations in the great fisheries of northern Europe viewed in the light of biological research. Rapp. P.v. Réun. Cons. perm. int. Explor. Mer 20: 1-228

Hjort. J. (1926). Fluctuations in the year classes of important food fishes. J. Cons. perm. int. Explor. Mer 1: 5-38

Hutchings, L., Armstrong, D. A., Mitchell-Innes, B. A. (1986). The frontal zone in the southern Benguela current. In: Nihoul, J. C. J. (ed.) Marine interfaces ecohydrodynamics. Elsevier, Amsterdam, p. 67-94

Jacquaz, B., A.ble, K. W., Leggett, W. C. (1977). Seasonal distribution, abundance, and growth of larval capelin (Mallotus villosus) in the St. Lawrence estuary and northwestern Gulf of St. Lawrence. J. Fish. Res. Bd Can. 34: $2015-2029$
Kiørboe, T (1991). Pelagic fisheries and spatio-temporal variability in zooplankton productivity. Proceedings of the Fourth International Conference on Copepoda. Bull. Plankton Soc. Japan Spec. Vol.: 229-249

Kiorboe, T., Johansen, K. (1986). Studies of a larval herring (Clupea harengus L.) patch in the Buchan area. IV Zooplankton distribution and productivity in relation to hydrographic features. Dana 6: 37-51

Kiørboe, T., Kaas, H., Kruse, B., Møhlenberg, F., Tiselius, P., Aertebjerg, G. (1990) The structure of the pelagic food web in relation to water column stratification in the Skagerrak. Mar. Ecol. Prog. Ser. 59: 19-32

Kiørboe, T., Munk, P., Richardson, K., Christensen, V., Paulsen, H. (1988). Plankton dynamics and larval herring growth, drift and survival in a frontal area. Mar. Ecol. Prog. Ser. 44: 205-219

Laprise, R., Dodson, J. J. (1989). Ontogenic changes in the longitudinal distribution of two species of larval fish in a turbid well-mixed estuary. J. Fish Biol 35 (suppl. A): $39-47$

Last, J. M. (1980). The food of twenty species of fish larvae in the west-central North Sea. Fish. Res. Tech. Rep. MAFF Direct. Fish. Res., Lowestoft 60: 1-44

Legendre, L., Le Fèvre, J. (1989). Hydrodynamical singularities as controls of recycled versus export production in oceans. In: Berger, W. H., Smetacek, V. S., Wefer, G. (eds.) Productivity of the ocean: present and past. Wiley, Chichester, p. 49-63

Leiby, M. M. (1984). Life history and ecology of pelagic fish eggs and larvae. In: Steidinger, K. A., Walker, L. M. (eds.) Marine plankton life cycle strategies. CRC Press, Boca Raton, p. 121-140

Leim, A. H., Scott, W. B. (1966). Fishes of the Atlantic coast of Canada. Bull. Fish. Res. Bd Can. 155: 1-485

Levasseur, M. E., Fortier, L., Therriault, J.-C., Harrison, P. J. (in press). Phytoplankton dynamics in a turbulent coastal jet front. Mar. Ecol. Prog. Ser.

Miller, T J., Crowder, L. B., Rice, J. A., Marschall, E. A. (1988). Larval size and recruitment mechanisms in fishes: toward a conceptual framework. Can. J Fish. Aquat. Sci. 45: $1657-1670$

Muliin, M. M. (1988). Production and distribution of nauplii and recruitment variability - putting the pieces together. In: Rothschild, B. I (ed.) Toward a theory on biologicalphysical interactions in the world ocean. Kluwer Academic Publishers, Dordrecht, p. 297-320

Ohman, M. D. (1987). Energy sources for the recruitment of the sub-antarctic copepod Neocalanus tonsus. Limnol. Oceanogr. 32: 1317-1330

Ouellet, P., Dodson, J J. (1985). Dispersion and retention of anadromous rainbow smelt (Osmerus mordax) larvae in the middle estuary of the St. Lawrence River. Can. J. Fish. Aquat. Sci. 42: 332-341

Parent, S., Brunel, P. (1976). Aires et périodes de fraie du capelan (Mallotus villosus) dans l'estuaire et le golfe Saint-Laurent. Trav. Pêcheries Quèb. 45: 1-46

Parsons, T. R., Lalli, C. M. (1988). Comparative oceanic ecology of the plankton communities of the subarctic Atlantic and Pacific oceans. Oceanogr. mar. Biol. Ann. Rev. 26: $317-359$

Pianka, E. R. (1970). On r- and K-selection. Am. Nat. 104: $592-597$

Richardson, K. (1985). Plankton distribution and activity in the North Sea/Skagerrak-Kattegat frontal area in April 1984. Mar. Ecol. Prog. Ser. 26: 233-244

Runge, J. A. (1988). Should we expect a relationship between primary production and fisheries? The role of copepod dy- 
namics as a filter of trophic variability. Hydrobiologia 167/168: $61-71$

Runge, J. A., Simard, Y (1990). Zooplankton of the St. Lawrence estuary: the imprint of physical processes on its composition and distribution. In: El-Sabh, M. 1, Silverberg, N. (eds.) Oceanography of a large-scale system: the St. Lawrence. Lecture notes on coastal and estuarine studies, Vol. 39. Springer-Verlag, New York, p $296-320$

Sevigny, J.-M., Sinclair, M., El-Sabh, M. I., Poulet, S., Coote, A. (1979). Summer plankton distributions associated with the physical and nutrient properties of the Northwestern Gulf of St. Lawrence. J. Fish. Res. Bd Gan. 36: $187-203$

Sherman, K., Smith, W., Morse, W., Berman, M., Green, J., Ejsymont, L. (1984). Spawning strategies of fishes in relation to circulation, phytoplankton production, and pulses in zooplankton off the northeastern United States. Mar. Ecol. Prog. Ser. 18: 1-19

Sinclair, M. (1988). Marine populations: an essay on population regulation and speciation. University of Washington Press, Seattle

This article was submitted to the editor
Smith, S. L., Jones, B. H., Atkinson, L. P., Brink, K. H. (1986). Zooplankton in the upwelling fronts off Pt. Conception, California. In: Nihoul, J. C. J. (ed.) Marine interfaces ecohydrodynamics. Elsevier, Amsterdam, p. 195-213

Tang, C. L. (1980a). Mixing and circulation in the northwestern Gulf of St. Lawrence: a study of a buoyancy-driven current system. J. geophys. Res. 85: 2787-2796

Tang, C. L. (1980b). Observation of wavelike motion of the Gaspe Current. J. phys. Oceanogr. 10: 853-860

Tang, C. L. (1983). Cross-front mixing and frontal upwelling in a controlled quasi-permanent density front in the Gulf of St. Lawrence. J. phys. Oceanogr. 13: 1468-1481

Turner, J. T. (1984). The feeding ecology of some zooplankters that are important prey items of larval fish. NOAA Tech. Rep. NMFS 7: 1-28

Vésin, J.-P., Leggett, W. C., Able, K. W. (1981). Feeding ecology of capelin (Mallotus villosus) in the estuary and western Gulf of St. Lawrence and its multispecies implications. Can. J. Fish. Aquat. Sci. 38: 257-267

Yentsch, C. S., Menzel, D. W. (1963). A method for the determination of phytoplankton chlorophyll and phaeophytin by fluorescence. Deep Sea Res. 10: 221-231

Manuscript first received: February 28, 1992

Revised version accepted: July 2, 1992 